\title{
Suppression of Cocaine-Evoked Hyperactivity by Self- Adjuvanting and Multivalent Peptide Nanofiber Vaccines
}

\author{
Jai S. Rudra ${ }^{\dagger, \ddagger},{ }^{*}, \S$, Ye Ding ${ }^{\dagger, \S}$, Harshini Neelakantan ${ }^{\dagger}$, , Chunyong Ding ${ }^{\dagger}$, Rajagopal

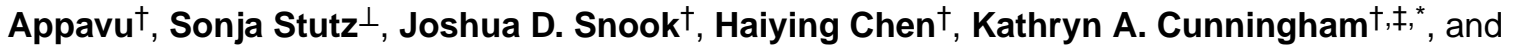 \\ Jia Zhou ${ }^{\dagger,}$, \\ †Department of Pharmacology \& Toxicology, University of Texas Medical Branch, 301 University \\ Blvd, Galveston, Texas 77555, United States \\ ${ }^{\perp}$ Center for Addiction Research, University of Texas Medical Branch, 301 University Blvd, \\ Galveston, Texas 77555, United States \\ FSealy Center for Vaccine Development, University of Texas Medical Branch, 301 University Blvd, \\ Galveston, Texas 77555, United States
}

\begin{abstract}
The development of anti-cocaine vaccines that counteract the rewarding effects of the drug are currently being investigated as adjunct therapies for prevention of relapse in abstinent users. However, cocaine is weakly immunogenic and requires conjugation to carrier proteins and coadministration with strong adjuvants, which carry the risk of local reactogenicity and systemic toxicity. Here we report synthetic and multivalent self-assembling peptide nanofibers as adjuvantfree carriers for cocaine vaccines. A novel cocaine hapten modified at the P3 site was conjugated to the $N$-terminus of an amphipathic self-assembling domain KFE8. In aqueous buffers the cocaine-KFE8 conjugate assembled into $\beta$-sheet rich nanofibers, which raised anti-cocaine antibodies without the need for added adjuvants in mice. Vaccinated mice were treated with cocaine and a significant negative correlation was observed between antibody levels and cocaineevoked hyperactivity. These totally synthetic and multivalent nanofibers with well-defined chemical composition represent the first generation of adjuvant-free cocaine vaccines.
\end{abstract}

\section{Graphical Abstract}

\footnotetext{
*Corresponding Authors: (J.S.R.) Phone: 409-772-9649. Fax: 409-772-9648. jarudra@utmb.edu. (J.Z.) Phone: 409-772-9748. Fax: 409-772-9648. jizhou@utmb.edu. (K.A.C.) Phone: 409-772-9640. Fax: 409-747-7050. kcunning@ utmb.edu.

$\$$ Author Contributions

J.S.R., Y.D., and H.N. contributed equally to this work.

Notes

The authors declare no competing financial interest.

Author Contributions

J.S.R., J.Z., and K.A.C. developed the idea, supervised the work, and wrote the manuscript. Y.D., C.D., and H.C. synthesized, purified, and characterized the cocaine haptens. R.A. synthesized and purified the peptide nanofiber vaccines conducted CD and TEM analysis. J.D.S. performed the vaccinations and investigated antibody titers. H.N. and S.S. performed locomotor studies and analyzed the data.

Supporting Information

The Supporting Information is available free of charge on the ACS Publications website at DOI: 10.1021/acschemneuro.5b00345. ELISA data showing dose and route dependent anti-cocaine antibody production in mice vaccinated with Coc-KFE8 nanofibers or controls as well as cocaine-evoked locomotor activity in nonresponder mice (PDF)
} 


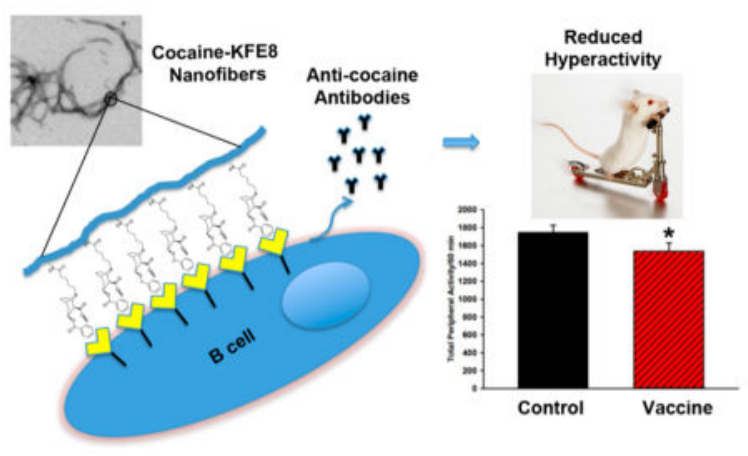

\section{Keywords}

Antibody; cocaine; hyperactivity; peptide-nanofiber; self-assembly; vaccine

Cocaine use disorder remains one of the greatest challenges on the public health agenda in the United States with ca. over 900000 Americans meeting the criteria for diagnosis in 2014. ${ }^{1}$ Despite the continued impact of this chronic health disorder, there are no United States Food and Drug Administration (FDA)-approved therapeutics either for cocaine use disorder or for the management of acute overdose. ${ }^{2,3}$ An emerging idea at the forefront of combating cocaine use disorder and forestalling overdose/toxicity is the development of vaccines, which generate cocaine-specific antibodies and prevent drug penetration across the blood-brain barrier. $^{3}$

A number of anti-cocaine vaccines are at various stages of preclinical and clinical development. ${ }^{3,4}$ However, a major limiting factor in the success of anti-cocaine vaccines is the degree and specificity of immunity evoked by the addictive drug analogue., ${ }^{5,6}$ The positioning of chemical linkers on cocaine for coupling to carrier proteins has been shown to be crucial for proper immune stimulation. ${ }^{7}$ Further administration of small molecules like cocaine will not elicit an immune response unless it is covalently attached to an immunogenic carrier protein and coadministered with an adjuvant. ${ }^{8}$ There is a severe lack of clinically approved adjuvants that are both effective and safe, and in the United States aluminum-based salts, collectively called "alum", or alum in combination with monophosphoryl lipid A (MPLA) are used a restricted only to intramuscular route of administration. ${ }^{8}$ Most experimental adjuvants under development are heterogeneous mixtures of plant or microbial extracts, which suffer from poor chemical definition and toxicity. ${ }^{9}$

A rapidly growing area in vaccine development and immunology is the design of nanoscaffolds with high surface-area- to-volume ratio for multivalent antigen presentation. ${ }^{10}$ Multivalent interactions between the antigen and immune cell receptors provide a significant enhancement in binding affinity and specificity leading to strong adaptive immune responses. ${ }^{11}$ Compared to other macromolecular architectures such as branched polymers, dendrimers, viruslike particles, and DNA, peptide-based scaffolds offer the advantage of ease of synthesis, characterization, chemical diversity, biocompatibility, and control over the primary sequence to obtain morphologies such as nanotubes, fibrils, nanoparticles, and 
vesicles. ${ }^{12,13}$ Furthermore, relatively long peptides can be realized using totally synthetic strategies whose purity and identity can be confirmed using mass-spectrometry, a key advantage for regulatory approval compared to heterogeneous mixtures.

Self-assembling peptides that assemble into $\beta$-sheet rich nanofibers in physiological buffers have been investigated recently as immune adjuvants for vaccine development. ${ }^{14-16}$ The ability of the nanofibers to self-assemble is maintained when other bioactive molecules are covalently attached at either terminus and presented on the surface of the nanofibers in highdensity multivalent arrays. ${ }^{15}$ When peptide or protein antigens are linked to self-assembling peptides, the resulting nanofibers are highly immunogenic and elicit strong antibody and cellular responses in mice without the need for any exogenous adjuvants. ${ }^{14}$ The adjuvanting activity of the nanofibers is not restricted to a particular primary sequence, route of immunization, or mouse strain. ${ }^{17,18}$ Vaccination with peptide nanofibers bearing disease specific epitopes has been shown to be protective in mouse models of malaria, ${ }^{19}$ cancer, ${ }^{18}$ and influenza. ${ }^{20}$ Here we investigated whether peptide nanofibers can act as effective adjuvants for vaccines against cocaine. A novel cocaine hapten modified at the P3 site (cocaine nitrogen-site) and linked to a self-assembling amphipathic peptide domain KFE8 (FKFEFKFE) (Scheme 1). In the present study, the cocaine-KFE8 (CocKFE8) conjugate assembled into nanofibers leading to multivalent display of cocaine in aqueous buffers. In mice, vaccination with CocKFE8 nanofibers without any added adjuvants induced anticocaine antibodies and blunted the effects of cocaine-evoked hyperactivity.

Cocaine haptens modified at the methyl ester (P1), benzoate (P2), $N$-methyl amino (P3), and two-carbon bridge (P4) moieties of cocaine have been previously reported. ${ }^{21}$ However, most of these haptens did not reach clinical trials except TA-CD with linker at the P3 position. ${ }^{6}$ To ensure that an improved immune response may be obtained, we designed a hapten modified at the $\mathrm{P} 3$ position distal from the binding region present in cocaine. For the synthesis of the hapten, compound 4 (YD0112) was prepared from cocaine hydrochloride in five synthetic steps as shown in Scheme 1. The key intermediate norcocaine 2 was synthesized by Ndemethylation of cocaine (1) using $\alpha$-choroethyl chloroformate ${ }^{22}$ in a total yield of $79 \%$ (three steps). Alkylation of norcocaine by the treatment with benzyl 5-bromopentanoate in the presence of $\mathrm{K}_{2} \mathrm{CO}_{3}$ and $\mathrm{KI}$ in acetone produced the compound $\mathbf{3}$ in $73 \%$ yield. Reduction of the benzyl ester 3 catalyzed by $10 \% \mathrm{Pd} / \mathrm{C}$ in the presence of hydrogen (1 atm) provided the hapten YD0112 (4) in 75\% yield. For synthesis of the immunogen (8), peptide KFE8 (FKFEFKFE) (5) with a triple glycine spacer at its N-terminus (GGG-KFE8) was synthesized using solid phase Fmoc chemistry. The N-terminal Fmoc was removed using $20 \%$ piperidine to yield a primary amine (6). Compound $\mathbf{4}$ was then coupled with $\mathbf{6}$ on resin using HBTU/DIEA with stirring overnight to yield cocaine-KFE8 conjugate (7). The conjugate was cleaved from the resin using 95\% TFA/2.5\% $\mathrm{H}_{2} \mathrm{O} / 2.5 \%$ triisopropyl silane cocktail, crashed in diethyl ether, purified using reverse-phase HPLC using water acetonitrile gradients on a $\mathrm{C} 18$ column, and freeze-dried to yield $\mathbf{8}$.

To determine the assembly and secondary structure characteristics of CocKFE8 (8) the conjugate was dissolved in pure water $(1 \mathrm{mM})$, incubated overnight $\left(4^{\circ} \mathrm{C}\right)$, and diluted in PBS $(0.33 \mathrm{mM})$ to induce fibrillization for $4 \mathrm{~h}$ at room temperature. Control fibers of peptide KFE8 were prepared in similar fashion and aggregates were analyzed by transmission 
electron microscopy. Results indicated that the CocKFE8 conjugate assembled into nanofibers (Figure 1B) similar to KFE8 with fibrillar morphology (Figure 1A) suggesting that the presence of cocaine did not inhibit the self-assembly process significantly. The secondary structure of CocKFE8 nanofibers compared to KFE8 nanofibers was investigated using circular dichrosim spectroscopy. Spectra for peptide KFE8 showed signals at $\sim 218$ and $\sim 205 \mathrm{~nm}$ indicative of $\beta$-sheet secondary structure and $\pi-\pi$ effects of Phe aromatic groups, respectively. Spectra of CocKFE8 conjugate showed a loss of signal at $205 \mathrm{~nm}$ suggesting weakened $\pi-\pi$ stacking (Figure 1C). Nonetheless, this did not significantly affect the ability of the conjugate to self-assemble into nanofiber scaffolds, which is crucial for eliciting adjuvant-free immune responses. ${ }^{17}$

To assess immunogenicity, dose dependence, and best route of CocKFE8 delivery, C57BL6 mice were vaccinated either subcutaneously (SC) or intraperitoneally (IP) with three doses of CocKFE8 nanofibers $(10,50$, and $100 \mu \mathrm{g}$ ) and boosted with the same dose at 21, 42, and 63 days (timeline, Figure 2). As a control, a commercially available cocaine-BSA conjugate (50 $\mu \mathrm{g}$ via SC and IP routes) was included. ELISA data indicated that $50 \mu \mathrm{g}$ of CocKFE8 nanofibers delivered via the IP route elicited the best antibody responses, as assessed by ELISA, compared to other routes and doses (Figure S1). Delivery of CocKFE8 nanofibers via the $\mathrm{SC}$ route failed to elicit any antibodies. In previous investigations, nanofiber vaccines using protein and peptide antigens have been immunogenic by both SC and IP routes. Both of these routes are routinely used in rodents to assess vaccine efficacy. Our hypothesis is that the vaccine administered IP led to the recruitment of peritoneal macrophages and efficient processing by antigen-presenting cells as reported previously. ${ }^{16}$ It is possible that administration of the vaccine via the SC route with a depot-forming adjuvant would lead to stronger antibody responses. Furthermore, cocaine-BSA conjugates delivered through IP and $\mathrm{SC}$ routes failed to induce anti-cocaine antibodies suggesting that cocaine-carrier conjugates are ineffective at inducing antibody responses without added adjuvants (Figure S1).

To assess antibody functionality and suppression of cocaine-evoked hyperactivity in vivo, mice were vaccinated with $50 \mu \mathrm{g}$ of CocKFE8 nanofibers IP and boosted according schedule shown in Figure 2. Control mice were injected with phosphate-buffered saline (PBS). The sera were analyzed using ELISA and data indicated that CocKFE8 nanofibers induced anticocaine antibody responses without the need for exogenous adjuvants (CocKFE8 vs control, $p<0.05$; Figure 2A). A broad distribution in antibody levels was observed and to assess functionality and specificity for cocaine in behavioral assessments, vaccinated mice were divided into two groups. Mice with absorbance values lower than the control (PBS-treated) group mean plus three times the standard deviation (i.e., absorbance $<0.05$, represented by the dashed line, Figure 2A) were defined as "CocKFE8 nonresponders" (Figure 2A). All other vaccinated mice with significantly higher absorbance values ( $p<0.05$ vs control and CocKFE8 nonresponders, Figure 2A) were defined as "CocKFE8 responders". The number of nonresponders was approximately $30 \%$, which is similar to what has been observed using cocaine-carrier conjugate vaccines in clinical trials ( $67 \%$ responders). ${ }^{23}$ This attests to the fact that small molecule drugs are poorly immunogenic and that principles of vaccine development applied to infectious diseases cannot be directly translated to addiction vaccines. The nonresponders were separated and treated as an independent cohort for behavior analyses since they were immunologically different from the controls and 
displayed significantly lower antibody levels relative to responders (CocKFE8 nonresponders vs CocKFE8 responders, $p<0.05$; Figure 2A).

Locomotor activity was measured in mice two weeks after the last boost. ${ }^{24,25}$ Mice were removed from their home cages and placed in activity monitors for $60 \mathrm{~min}$ to assess spontaneous motor activity in vaccinated and control groups. No significant difference in the timecourse (Figure 2B) or total spontaneous (peripheral) activity ( $p>0.05$, ns; Figure 2C) was observed between control and CocKFE8-responder mice. Total peripheral activity in nonresponder mice did not differ relative to control mice ( $p>0.05$, ns; Figure S2). Following the assessment of spontaneous motor activity, mice were injected with cocaine $(15 \mathrm{mg} / \mathrm{kg}, \mathrm{IP})$ and evaluated for locomotor activity for $60 \mathrm{~min}$. The effect of vaccine to suppress cocaine-evoked hyperactivity was apparent in the first 15 min time bin following cocaine injection (Figure 2D) and the CocKFE8 responders exhibited a modest, yet significant, decrease in total cocaine-evoked peripheral activity ( $p<0.05$; Figure 2E). Cocaine-evoked peripheral activity in nonresponder mice did not differ relative to control mice ( $p>0.05$, ns; Figure S2). A significant negative correlation was observed between antibody (absorbance) levels and total peripheral activity for individual vaccinated mice, suggesting that CocKFE8 nanofibers induced cocaine-specific antibodies (Figure 3).

The current landscape of cocaine vaccine development relies heavily on developing antigenicity based upon the conjugation of the drug to carrier proteins from animal and bacterial sources and formulating the cocaine-carrier conjugates into emulsions using exogenous adjuvants. ${ }^{8}$ Recently, a cholera toxin B-cocaine conjugate vaccine (TA-CD) in combination with alum adjuvant has undergone multisite Phase III testing. ${ }^{23}$ After five rounds of immunizations $\sim 33 \%$ of the patients failed to achieve anti-cocaine antibody titers but all patients had antibodies against cholera toxin. ${ }^{23}$ Adverse events such as induration and erythema at the injection site were reported due to use of alum and further, alum is restricted to the intramuscular route, making it impossible to investigate needle-free avenues of vaccination that provide higher patient compliance rates. ${ }^{9,23}$ Also chronic cocaine exposure leads to the development of anti-cocaine IgM antibodies and the presence of $\operatorname{IgM}$ antibodies has been shown to be a poor marker for eliciting IgG antibody responses to cocaine vaccines. ${ }^{26}$ Furthermore, cocaine exposure associates with immune system suppression that could potentially lead to vaccine failures. ${ }^{27}$ Therefore, there is a need for novel cocaine vaccine strategies that can overcome the immunosuppressive effects associated with chronic cocaine exposure compared to toxin-based carriers and alum adjuvants and yet can be safely administered without significant concerns for toxicity.

Peptide nanofiber carriers reported here are attractive as antigen delivery scaffolds due to their inert and biocompatible nature. ${ }^{28}$ Synthetic peptides can be easily produced through standard peptide synthesis protocols and peptides incorporating non-natural amino acids or nonpeptidic moieties can be designed to reduce proteolysis and degradation of the vaccine in vivo. The chemical versatility of the self-assembling peptide platform allows for conjugation of TLR agonists and/or CD4 T helper epitopes during synthesis for enhanced immunogenicity and antibody production. Importantly, physical conjugation of TLR agonists will minimize their free dissemination into the surrounding tissue and reduce local inflammation. However, questions regarding mechanism of action of nanofiber vaccines and 
their in vivo fate and toxicity will need to be assessed prior to their efficient translation in to the clinic and will form an integral part of our future studies.

In conclusion, we designed and synthesized chemically defined self-adjuvanting cocaine vaccines composed of novel cocaine haptens and self-assembling peptide domains.

Immunological evaluation of cocaine nanofiber vaccines showed that anti-cocaine antibodies were elicited and counteracted the behavioral effects of the drug in mice. These totally synthetic and multivalent nanofibers with well-defined chemical composition represent the first generation of adjuvant-free cocaine vaccines that deserve further investigation.

\section{METHODS}

\section{General}

All commercially available starting materials and solvents were reagent grade and used without further purification. The key intermediates $\mathbf{2}^{22}$ and benzyl 5-bromopentanoate ${ }^{29}$ were synthesized following the reported procedures. Reactions were performed under a nitrogen atmosphere in dry glassware with magnetic stirring. Preparative column chromatography was performed using silica gel 60, particle size 0.063-0.200 mm (70-230 mesh, flash). Analytical TLC was carried out employing silica gel 60 F254 plates (Merck, Darmstadt). The developed chromatogram was visualized by UV detection (254 nm). NMR spectra were recorded on a Bruker-300 $\left({ }^{1} \mathrm{H}, 300 \mathrm{MHz} ;{ }^{13} \mathrm{C}, 75 \mathrm{MHz}\right)$ spectrometer. ${ }^{1} \mathrm{H}$ and ${ }^{13} \mathrm{C}$ NMR spectra were recorded with TMS as an internal reference. Chemical shifts downfield from TMS were expressed in ppm, and $J$ values were given in Hz. Highresolution mass spectra (HRMS) were obtained from Thermo Fisher LTQ Orbitrap Elite mass spectrometer. Parameters include the following: nano ESI spray voltage was $1.8 \mathrm{kV}$, capillary temperature was $275^{\circ} \mathrm{C}$, and the resolution was 60000 ; ionization was achieved by positive mode. Purity of final compounds was determined by analytical HPLC, which was carried out on a Shimadzu HPLC system (model: CBM-20A LC-20AD SPD-20A UV/vis). HPLC analysis conditions: Waters $\mu$ Bondapak C18 $(300 \mathrm{~mm} \times 3.9 \mathrm{~mm})$, flow rate $0.5 \mathrm{~mL} /$ min, UV detection at 270 and $254 \mathrm{~nm}$, linear gradient from $10 \%$ acetonitrile in water to $100 \%$ acetonitrile in $20 \mathrm{~min}$, followed by $30 \mathrm{~min}$ of the last-named solvent.

\section{Synthesis of 5-((1R,2R,3S,5S)-3-(Benzoyloxy)-2-(methoxycar-bonyl)-8- azabicyclo[3.2.1]octan-8-yl)pentanoic Acid (4)}

To a stirring solution of $2(279 \mathrm{mg}, 0.97 \mathrm{mmol})$ and $\mathrm{K}_{2} \mathrm{CO}_{3}(268 \mathrm{mg}, 1.94 \mathrm{mmol})$ in acetone $(10 \mathrm{~mL})$ was added benzyl 5-bromopentanoate $(314 \mathrm{mg}, 1.16 \mathrm{mmol})$ and $\mathrm{KI}(161 \mathrm{mg}, 0.97$ $\mathrm{mmol}$ ) at room temperature. The resulting mixture was refluxed for $24 \mathrm{~h}$. After cooling, the mixture was concentrated in vacuo to give an oily residue. The residue was dissolved in dichloromethane and washed with brine, dried over anhydrous $\mathrm{Na}_{2} \mathrm{SO}_{4}$, filtered, and evaporated to give an oily crude product. The crude product was purified by silica gel column; elution with $20 \%$ EtOAc in hexane afforded the desired product $\mathbf{3}(337 \mathrm{mg}, 73 \%)$ as an amorphous gel. ${ }^{1} \mathrm{H}$ NMR $\left(300 \mathrm{MHz}, \mathrm{CDCl}_{3}\right) \delta 8.09-8.01(\mathrm{~m}, 2 \mathrm{H}), 7.54(\mathrm{~m}, 1 \mathrm{H}), 7.49$ $7.29(\mathrm{~m}, 7 \mathrm{H}), 5.26(\mathrm{dt}, J=12.0,6.0 \mathrm{~Hz}, 1 \mathrm{H}), 5.14(\mathrm{~s}, 2 \mathrm{H}), 3.68(\mathrm{~s}, 4 \mathrm{H}), 3.32(\mathrm{~d}, J=3.0 \mathrm{~Hz}$, $1 \mathrm{H}), 3.09-2.98(\mathrm{~m}, 1 \mathrm{H}), 2.53-2.34(\mathrm{~m}, 3 \mathrm{H}), 2.25(\mathrm{tt}, J=12.0,6.0 \mathrm{~Hz}, 2 \mathrm{H}), 2.14-1.93(\mathrm{~m}$, 2H), 1.91-1.82 (m, 1H), 1.79-1.64 (m, 4H), 1.52-1.35 (m, 2H). ${ }^{13} \mathrm{C}$ NMR (75 MHz, 
$\left.\mathrm{CDCl}_{3}\right) \delta 173.48,170.73,166.19,136.12,132.91,130.43,129.72,129.72,128.56,128.56$, $128.33,128.33,128.23,128.23,128.19,67.40,66.10,62.64,60.51,52.22,51.24,50.38$, $35.71,34.09,28.43,26.09,25.50,22.53$.

A stirring solution of $\mathbf{3}(337 \mathrm{mg}, 0.70 \mathrm{mmol})$ and $10 \% \mathrm{Pd} / \mathrm{C}(33.7 \mathrm{mg})$ in $\mathrm{MeOH}(10 \mathrm{~mL})$ was evacuated and backfilled with $\mathrm{H}_{2}$ at room temperature and one atmospheric pressure. After $12 \mathrm{~h}$, the mixture was filtered over a pad of Celite and the solvent was evaporated in vacuo. The resulting residue was further purified by silica gel column; elution with $10 \%$ $\mathrm{MeOH}$ in $\mathrm{CH}_{2} \mathrm{Cl}_{2}$ afforded the desired product 4 (205 mg, 75\%) as a colorless amorphous gel. HPLC purity $98.0 \%\left(t_{\mathrm{R}}=10.82 \mathrm{~min}\right) .{ }^{1} \mathrm{H}$ NMR $\left(300 \mathrm{MHz}, \mathrm{CD}_{3} \mathrm{OD}\right) \delta 8.07-7.94(\mathrm{~m}$, 2H), 7.70-7.57 (m, 1H), 7.55-7.41 (m, 2H), $5.36(\mathrm{dt}, J=12.0,6.2 \mathrm{~Hz}, 1 \mathrm{H}), 3.94(\mathrm{~m}, 1 \mathrm{H})$, $3.70(\mathrm{~s}, 3 \mathrm{H}), 3.56(\mathrm{~m}, 1 \mathrm{H}), 3.23(\mathrm{dd}, J=6.2,3.1 \mathrm{~Hz}, 1 \mathrm{H}), 2.54(\mathrm{t}, J=7.2 \mathrm{~Hz}, 2 \mathrm{H}), 2.42(\mathrm{td}, J$ $=12.0,3.1 \mathrm{~Hz}, 1 \mathrm{H}), 2.22(\mathrm{~m}, 4 \mathrm{H}), 2.03(\mathrm{~m}, 1 \mathrm{H}), 1.88(\mathrm{~m}, 2 \mathrm{H}), 1.75-1.48(\mathrm{~m}, 4 \mathrm{H}) .{ }^{13} \mathrm{C} \mathrm{NMR}$ (75 MHz, $\left.\mathrm{CD}_{3} \mathrm{OD}\right) \delta 184.81,175.50,169.72,136.94,133.80,133.10,133.10,132.10$, 132.10, 70.57, 65.68, 65.36, 55.94, 54.90, 52.80, 40.92, 38.49, 31.49, 28.68, 28.39, 27.27. HRMS Calcd for $\mathrm{C}_{21} \mathrm{H}_{28} \mathrm{NO}_{6}:[\mathrm{M}+\mathrm{H}]^{+} 390.1917$; found 390.1920 .

\section{Synthesis of Cocaine-KFE8 Conjugate (8)}

Peptide $\mathrm{NH}_{2}$-GGGFKFEFKFE-CONH was synthesized using standard Fmoc Chemistry on a CS Bio-CS336X solid phase peptide synthesizer (CS Bio, Menolo Park, CA). Rink amide MBHA (Novabiochem, Billerica, MA) was swelled in dry DMF (dimethylformamide) for 1 $\mathrm{h}$, and amino acids were coupled using HBTU ( $O$-(benzotriazol-1-yl)- $N, N, N^{\prime}, N^{\prime}$ tetramethyluronium hexafluorophosphate)/DIEA (diisopropylethylamine) for $30 \mathrm{~min}$ followed by HOBt (1-hydroxybenzotriazole)/ DIC (diisopropylcarbodimide) for $2 \mathrm{~h}$ to yield product 5. Following deprotection (20\% piperidine in DMF) of the N-terminal glycine (compound 6), cocaine hapten (4) was coupled to the peptide using HBTU/DIEA for $2 \mathrm{~h}$. The conjugate 7 was cleaved from the resin using a 95\% TFA $/ 2.5 \%$ water $/ 2.5 \%$ triisopropyl silane cocktail and washed three times in diethyl ether to yield the immunogen $\mathbf{8}$. The crude product was purified by reverse-phase HPLC (C18 column) using acetonitrile/ $\mathrm{H}_{2} \mathrm{O}$ gradients to $>90 \%$ purity and peptide mass was confirmed by MALDI using $\alpha$-cyano-4hydroxycinnamic acid matrix (Bruker Daltonics, Billerica, MA). Molecular weight of the conjugate $\mathbf{8}$ was verified using a Bruker MALDI-TOF mass spectrometer; calcd: [M + $\mathrm{H}]^{+}$1662.54; found 1663.16. Peptide was lyophilized and stored at $4{ }^{\circ} \mathrm{C}$, and endotoxin levels were tested using a limulus amebocyte lystae (LAL) chromogenic end point assay (Lonza, Hopkinton, MA) at the same volume and concentration used for immunizations and were found to be less than $0.1 \mathrm{EU} / \mathrm{mL}$ and within acceptable limits.

\section{Transmission Electron Microscopy (TEM)}

Stock solutions of $1 \mathrm{mM}$ peptides were allowed to fibrillize in water overnight at room temperature, diluted in PBS to $0.3 \mathrm{mM}$, and applied to 300 mesh copper grids with carbon support film (Quantifoil, Germany). The grids were negatively stained with $2 \%$ uranyl acetate, and imaged on a JEM1400 TEM (JEOL) instrument equipped with $\mathrm{LaB}_{6}$ electron gun and digital cameras. Images were viewed and recorded with an Ultrascan 1000 camera (Gatan, Pleasanton, CA). 


\section{Circular Dichroism Spectroscopy (CD)}

CD experiments were carried out on a JASCO J-815 CD spectrometer. Peptide stock solutions $(1 \mathrm{mM})$ were made in ultrapure water and diluted to working concentrations before use. The CD wavelength range was from 300 to $195 \mathrm{~nm}$ with a scanning speed of $0.3 \mathrm{~nm} / \mathrm{s}$ and a bandwidth of $0.5 \mathrm{~nm}$. CD spectra were recorded at room temperature with a fixedpath-length $(1 \mathrm{~mm})$ cell. The solvent background contribution was subtracted.

\section{Drug}

(-)-Cocaine (National Institute on Drug Abuse) was dissolved in $0.9 \% \mathrm{NaCl}$.

\section{Animals and Immunizations}

Male mice (C57BL/6, 5-6 weeks old) purchased from Jackson Laboratories (Bar Harbor, $\mathrm{ME})$. Mice were allowed to acclimate for 5-7 days in a colony room at a constant temperature $\left(21-23{ }^{\circ} \mathrm{C}\right)$ and humidity $(45-50 \%)$ on a $12 \mathrm{~h}$ light-dark cycle (lights on 0700$1900 \mathrm{~h}$ ). Mice were housed five per cage with food and water available ad libitum throughout all phases of the studies. For vaccination, the stock solution of Cocaine-KFE8 (CocKFE8) peptide nanofibers was prepared freshly each time. First the peptide was dissolved in water ( $8 \mathrm{mM}$ stock), incubated overnight, and diluted 4-fold in PBS (2 mM stock) $4 \mathrm{~h}$ prior to vaccination. At the injected concentration, CocKFE8 solution was a viscous gel and could be easily manipulated using a 25-gauge syringe. Mice were vaccinated IP or SC route with $50 \mu \mathrm{L}$ of CocKFE8 nanofibers and boosted with the same dosage at days 21, 42, and 63. Cocaine-BSA conjugate was purchased from Fitzgerald Industries (Acton, MA) and used without further modification. Blood was collected via the submandibular vein 2 weeks after the last boost and sera stored at $-80^{\circ} \mathrm{C}$. All experiments were conducted under approved protocols by the University of Texas Medical Branch Institutional Animal Care and Use Committee and repeated independently twice with 10-15 mice per group per experiment.

\section{ELISA Methods}

High-binding ELISA plates (eBioscience, San Diego, CA) were coated with $20 \mu \mathrm{g} / \mathrm{mL}$ of CocKFE8 nanofibers in PBS overnight at $4{ }^{\circ} \mathrm{C}$ and blocked with $200 \mu \mathrm{L}$ of $1 \%$ BSA in PBST (0.5\% Tween-20 in PBS) for $1 \mathrm{~h}$. Serum was diluted in PBST (1:100) and applied (100 $\mu \mathrm{L} /$ well) for $1 \mathrm{~h}$ at room temperature followed by peroxidase-conjugated goat antimouse IgG (H+L) (Jackson Immuno Research, West Grove, PA) (1:5000 in 1\% BSA-PBST, $100 \mu \mathrm{L} /$ well). Plates were developed using TMB substrate (100 $\mu \mathrm{L} /$ well, eBioscience, San Diego, CA), the reaction stopped using $50 \mu \mathrm{L}$ of $1 \mathrm{M}$ phosphoric acid, and absorbance measured at $450 \mathrm{~nm}$. Absorbance values of PBS (no antigen)-coated wells were subtracted to account for background. Vaccinated mice with titers lower than three times the standard deviation of the mean titer for the control group (PBS-treated; titers lower than 0.05 absorbance units) were defined as "CocKFE8 nonresponders" and all other vaccinated mice were defined as "CocKFE8 responders" and compared to control mice in the behavioral studies. 


\section{Locomotor Activity}

Two weeks after the last booster dose, blood collection was performed in vaccinated and PBS-treated control mice for antibody detection using ELISA. The following day, spontaneous motor activity and cocaine-evoked locomotor activity were assessed in control and vaccinated mice under low light conditions using an open field activity system (San Diego Instruments, San Diego, CA) according to a modified protocol from previous publications. ${ }^{24,25}$ Clear Plexiglas chambers $\left(40 \times 40 \times 40 \mathrm{~cm}^{3}\right)$ were surrounded by two $4 \times$ 4 photobeam arrays. The lower array, positioned level with the chamber floor recorded horizontal activity. Peripheral activity was defined as the sum of photobeam breaks that occurred within the outer $12 \mathrm{~cm}$ band of the activity monitor. For all experiments, spontaneous motor activity was recorded in the activity monitors for the first $60 \mathrm{~min}$. Immediately following the assessment of spontaneous motor activity, mice were injected with cocaine $(15 \mathrm{mg} / \mathrm{kg}, 10 \mathrm{~mL} / \mathrm{kg}$; IP) and returned to the activity monitors for an additional hour to assess cocaine-evoked locomotor activity.

\section{Statistical Analysis}

Spontaneous and cocaine-evoked peripheral activity data were analyzed and are presented as mean total peripheral activity summed across the $60 \mathrm{~min}$ session for control, CocKFE8 responder, and CocKFE8 nonresponder groups, respectively (Figures 2C,E and S2). Differences in the mean total peripheral activity (spontaneous and cocaine-evoked) observed for the vaccinated mice (CocKFE8 responders and cocKFE8 nonresponders) relative to controls were analyzed using one-tailed Student's $t$ test. All statistical analyses were conducted with an experimentwise error rate of $a=0.05$. The antibody titers (absorbance measured using ELISA) and cocaine-evoked peripheral activity (counts/60 min) measures for individual mice were transformed by square root transformations to confirm normality of distribution. Transformed data were employed in Pearson's correlation analysis (SAS, version 9.4; Cary, NC).

\section{Supplementary Material}

Refer to Web version on PubMed Central for supplementary material.

\section{Acknowledgments}

Funding

This study was supported by NIH/NIDA R21 DA036663 (J.S.R., J.Z., and K.A.C.).

TEM studies were conducted at the Sealy Center for Structural Biology Cryo-electron Microscopy core lab, and we thank Michael Woodson for assistance with imaging.

\section{References}

1. Center for Behavioral Health Statistics and Quality. Behavioral health trends in the United States: Results from the 2014 National Survey on Drug Use and Health. 2015. (HHS Publication No. SMA 15-4927, NSDUH Series H-50), retrieved from http://www.samhsa.gov/data/

2. Shen XY, Orson FM, Kosten TR. Vaccines against drug abuse. Clin Pharmacol Ther. 2012; 91:60. [PubMed: 22130115] 
3. Orson FM, Wang RF, Brimijoin S, Kinsey BM, Singh RAK, Ramakrishnan M, Wang HY, Kosten TR. The future potential for cocaine vaccines. Expert Opin Biol Ther. 2014; 14:1271. [PubMed: 24835496]

4. Kosten T, Domingo C, Orson F, Kinsey B. Vaccines against stimulants: cocaine and MA. Br J Clin Pharmacol. 2014; 77:368. [PubMed: 23509915]

5. Moreno AY, Janda KD. Current challenges for the creation of effective vaccines against drugs of abuse. Expert Rev Vaccines. 2011; 10:1637. [PubMed: 22085165]

6. Ramakrishnan M, Kinsey BM, Singh RA, Kosten TR, Orson FM. Hapten Optimization for Cocaine Vaccine with Improved Cocaine Recognition. Chem Biol Drug Des. 2014; 84:354. [PubMed: 24803171]

7. Ino A, Dickerson TJ, Janda KD. Positional linker effects in haptens for cocaine immunopharmacotherapy. Bioorg Med Chem Lett. 2007; 17:4280. [PubMed: 17531484]

8. Alving CR, Matyas GR, Torres O, Jalah R, Beck Z. Adjuvants for vaccines to drugs of abuse and addiction. Vaccine. 2014; 32:5382. [PubMed: 25111169]

9. Aguilar JC, Rodriguez EG. Vaccine adjuvants revisited. Vaccine. 2007; 25:3752. [PubMed: 17336431]

10. Smith DM, Simon JK, Baker JR. Applications of nanotechnology for immunology. Nat Rev Immunol. 2013; 13:592. [PubMed: 23883969]

11. Englund EA, Wang DY, Fujigaki H, Sakai H, Micklitsch CM, Ghirlando R, Martin-Manso G, Pendrak ML, Roberts DD, Durell SR, Appella DH. Programmable multivalent display of receptor ligands using peptide nucleic acid nanoscaffolds. Nat Commun. 2012; 3:614. [PubMed: 22233624]

12. Petkau-Milroy K, Brunsveld L. Supramolecular chemical biology; bioactive synthetic selfassemblies. Org Biomol Chem. 2013; 11:219. [PubMed: 23160566]

13. Kushner AM, Guan ZB. Modular Design in Natural and Biomimetic Soft Materials. Angew Chem, Int Ed. 2011; 50:9026.

14. Rudra JS, Tian YF, Jung JP, Collier JH. A self-assembling peptide acting as an immune adjuvant. Proc Natl Acad Sci U S A. 2010; 107:622. [PubMed: 20080728]

15. Wen Y, Collier JH. Supramolecular peptide vaccines: tuning adaptive immunity. Curr Opin Immunol. 2015; 35:73. [PubMed: 26163376]

16. Chen JJ, Pompano RR, Santiago FW, Maillat L, Sciammas R, Sun T, Han HF, Topham DJ, Chong AS, Collier JH. The use of self-adjuvanting nanofiber vaccines to elicit high-affinity B cell responses to peptide antigens without inflammation. Biomaterials. 2013; 34:8776. [PubMed: 23953841]

17. Rudra JS, Sun T, Bird KC, Daniels MD, Gasiorowski JZ, Chong AS, Collier JH. Modulating Adaptive Immune Responses to Peptide Self-Assemblies. ACS Nano. 2012; 6:1557. [PubMed: 22273009]

18. Huang ZH, Shi L, Ma JW, Sun ZY, Cai H, Chen YX, Zhao YF, Li YMa. Totally Synthetic, SelfAssembling, Adjuvant-Free MUC1 Glycopeptide Vaccine for Cancer Therapy. J Am Chem Soc. 2012; 134:8730. [PubMed: 22587010]

19. Rudra JS, Mishra S, Chong AS, Mitchell RA, Nardin EH, Nussenzweig V, Collier JH. Selfassembled peptide nanofibers raising durable antibody responses against a malaria epitope. Biomaterials. 2012; 33:6476. [PubMed: 22695068]

20. Chesson CB, Huelsmann EJ, Lacek AT, Kohlhapp FJ, Webb MF, Nabatiyan A, Zloza A, Rudra JS. Antigenic peptide nanofibers elicit adjuvant-free CD8(+) T cell responses. Vaccine. 2014; 32:1174. [PubMed: 24308959]

21. Moreno AY, Janda KD. Immunopharmacotherapy: vaccination strategies as a treatment for drug abuse and dependence. Pharmacol, Biochem Behav. 2009; 92:199. [PubMed: 19350728]

22. Zhou J, Zhang A, Klass T, Johnson KM, Wang CZ, Ye YP, Kozikowski AP. Biaryl analogues of conformationally constrained tricyclic tropanes as potent and selective norepinephrine reuptake inhibitors: synthesis and evaluation of their uptake inhibition at monoamine transporter sites. J Med Chem. 2003; 46:1997. [PubMed: 12723962]

23. Kosten TR, Domingo CB, Shorter D, Orson F, Green C, Somoza E, Sekerka R, Levin FR, Mariani JJ, Stitzer M, Tompkins DA, Rotrosen J, Thakkar V, Smoak B, Kampman K. Vaccine for cocaine 
dependence: A randomized double-blind placebo-controlled efficacy trial. Drug Alcohol Depend. 2014; 140:42. [PubMed: 24793366]

24. Valencia F, Bubar MJ, Milligan G, Cunningham KA, Bourne N. Influence of methamphetamine on genital herpes simplex virus type 2 infection in a mouse model. Sex Transm Dis. 2012; 39:720. [PubMed: 22902670]

25. Yan J, Mei FC, Cheng H, Lao DH, Hu Y, Wei J, Patrikeev I, Hao D, Stutz SJ, Dineley KT, Motamedi M, Hommel JD, Cunningham KA, Chen J, Cheng X. Enhanced Leptin Sensitivity, Reduced Adiposity, and Improved Glucose Homeostasis in Mice Lacking Exchange Protein Directly Activated by Cyclic AMP Isoform 1. Molecular and cellular biology. 2013; 33:918. [PubMed: 23263987]

26. Orson FM, Rossen Shen X, Lopez AY, Wu Y, Kosten TR. Spontaneous developmnent of IgM anticocaine antibodies in habitual cocaine users: effect on IgG antibody responses to a cocaine cholera toxin B conjugate vaccine. Am J Addict. 2013; 22:169. [PubMed: 23414504]

27. Pellegrino TC, Dunn KL, Bayer BM. Mechanisms of cocaine-induced decreases in immune cell function. Int Immunopharmacol. 2001; 1:665. [PubMed: 11357879]

28. Matson JB, Stupp SI. Self-assembling peptide scaffolds for regenerative medicine. Chem Commun. 2012; 48:26.

29. Rybczynski PJ, Zeck RE, Dudash J Jr, Combs DW, Burris TP, Yang M, Osborne MC, Chen X, Demarest KT. Benzoxazinones as PPARgamma agonists. 2 SAR of the amide substituent and in vivo results in a type 2 diabetes model. J Med Chem. 2004; 47:196. [PubMed: 14695833] 


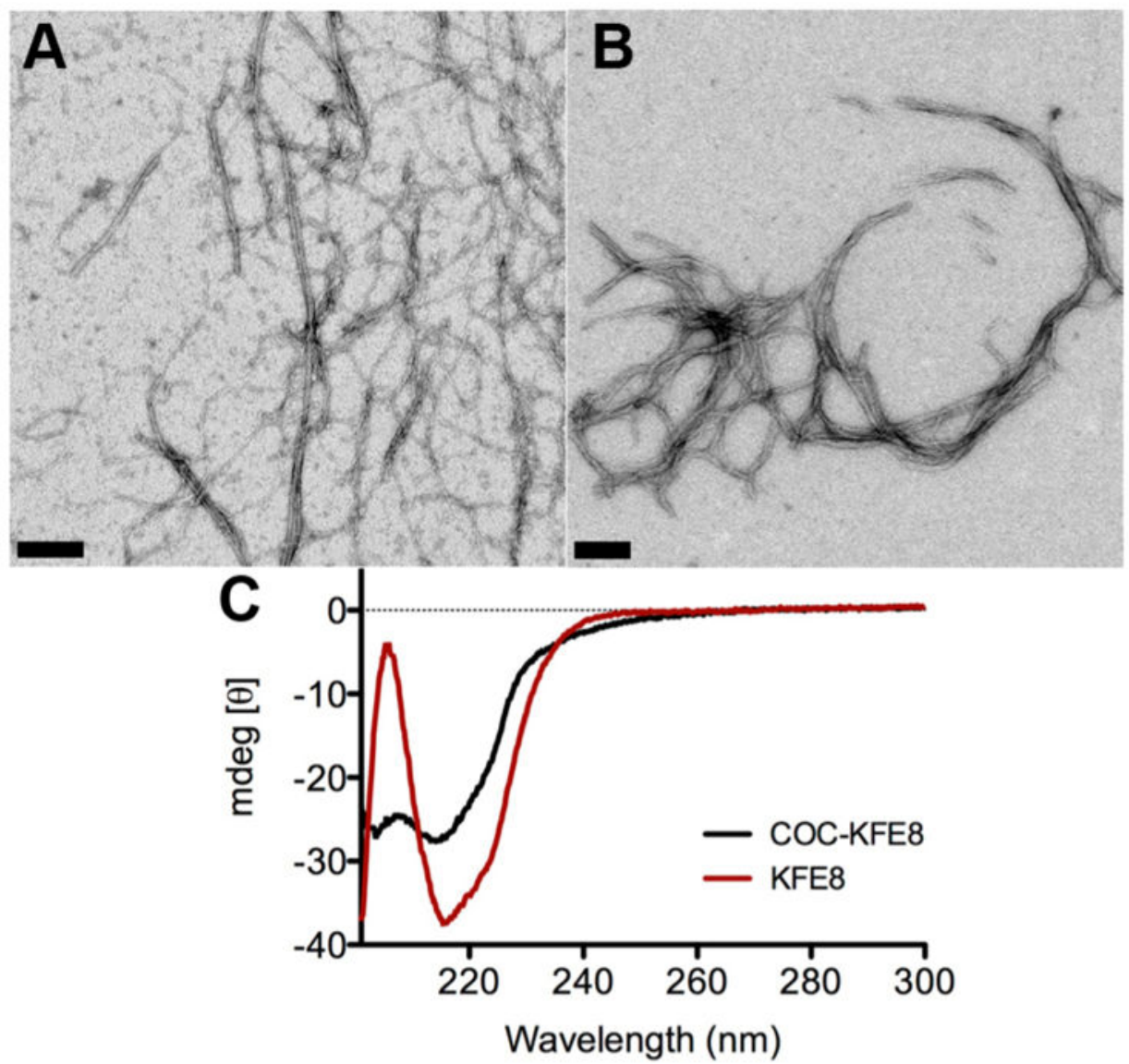

Figure 1.

Self-assembly and secondary structure analysis of CocKFE8 conjugates. (A) Nanofibers of KFE8 and (B) CocKFE8 as observed by transmission electron microscopy. Scale bar $=50$ nm. (C) CD spectra of CocKFE8 conjugate showing $\beta$-sheet rich secondary structure. Peptide concentration was $0.5 \mathrm{mM}$ in water. 

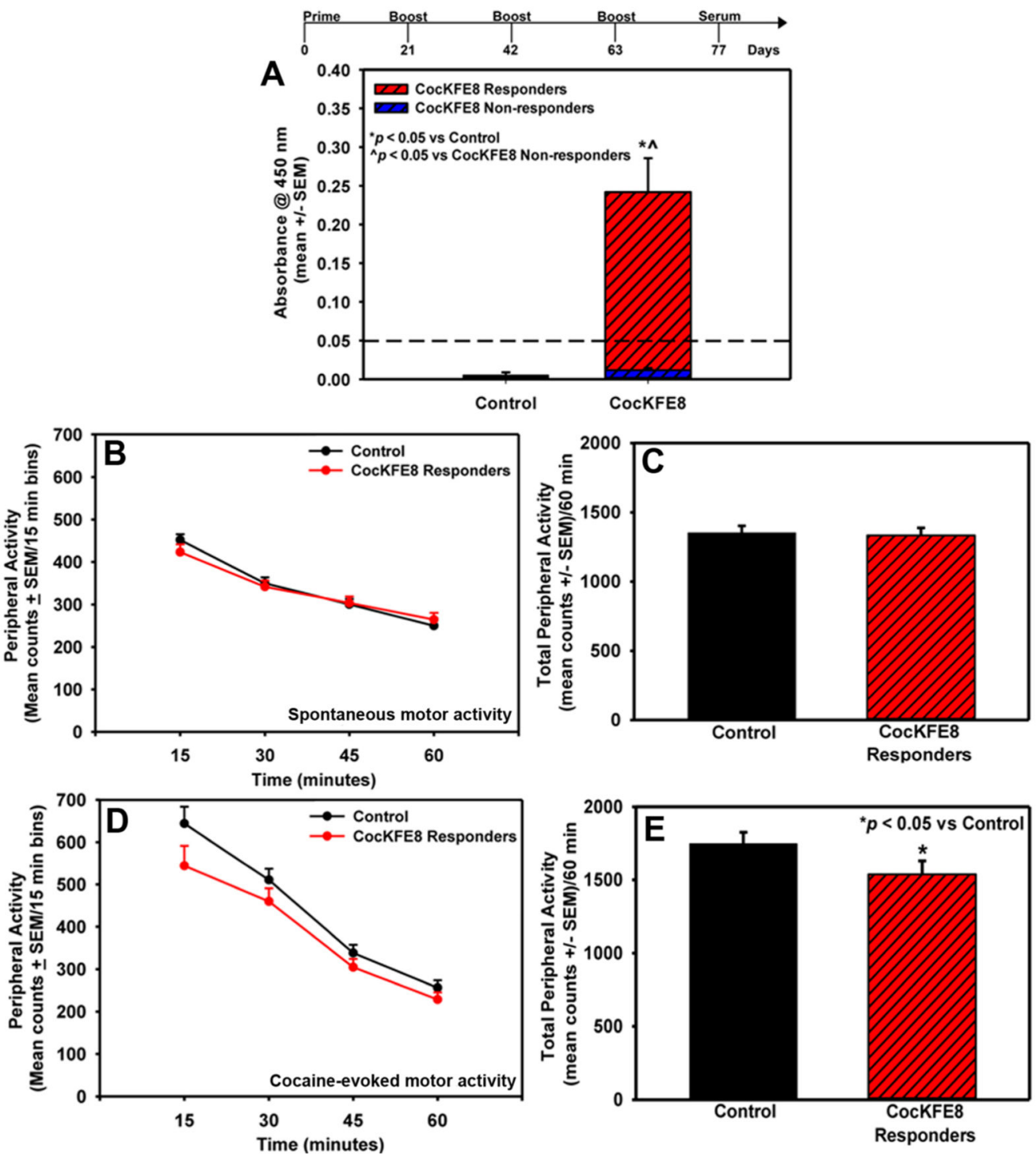

Figure 2.

Immunization regime, antibody responses, and suppression of cocaine-evoked hyperactivity in mice. (A) CocKFE8 nanofibers induced adjuvant-free antibody responses in mice as measured by ELISA and mice with absorbance values higher than the control (PBS-treated) group mean plus three times the standard deviation (i.e., $>0.05$ absorbance, represented by the dashed line) were defined as CocKFE8 responders $\left(* p<0.05\right.$ vs controls, ${ }^{\wedge} p<0.05$ vs CocKFE8 nonresponders). (B) Vaccination with CocKFE8 did not alter spontaneous locomotor activity $(p>0.05)$. (D) Mice responding to CocKFE8 nanofiber vaccines show blunted cocaine-evoked locomotor activity ( ${ }^{*} p<0.05$ vs control). The time course of peripheral activity is divided into $15 \mathrm{~min}$ time bins across the $60 \mathrm{~min}$ session for both spontaneous and cocaine-evoked locomotor activity. The mean total spontaneous and cocaine-evoked peripheral activity (counts/60 min) $( \pm$ SEM) is represented in panels $(C)$ and (E), respectively. 


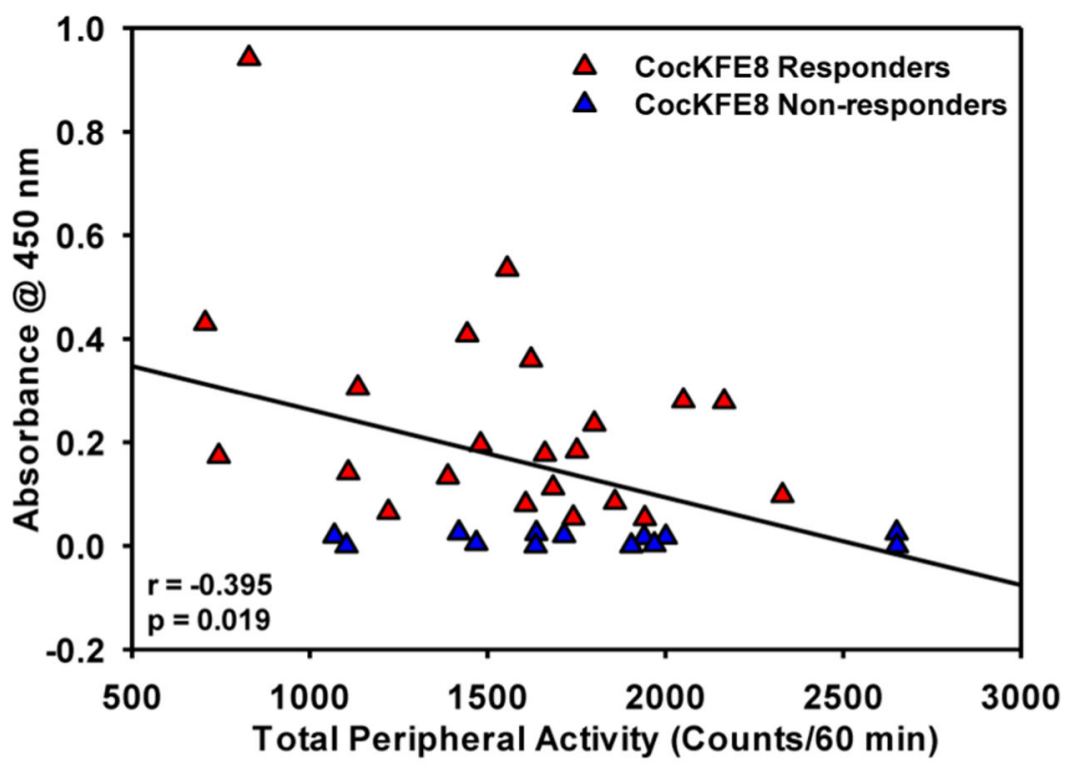

Figure 3.

Significant negative correlation between antibody titers and cocaine-evoked hyperactivity measures for individual mice $(r=-0.395 ; p<0.05)$. 

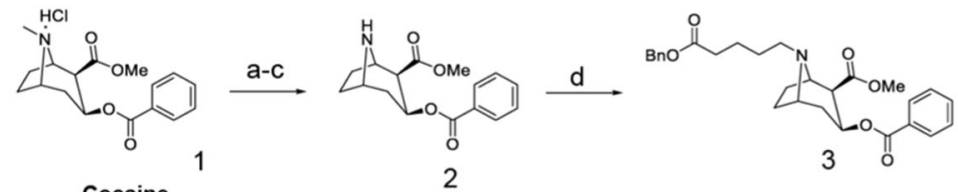

hydrochloride

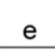

용

e<smiles>CCCCCCCCCCC=C(O)CCCC</smiles>
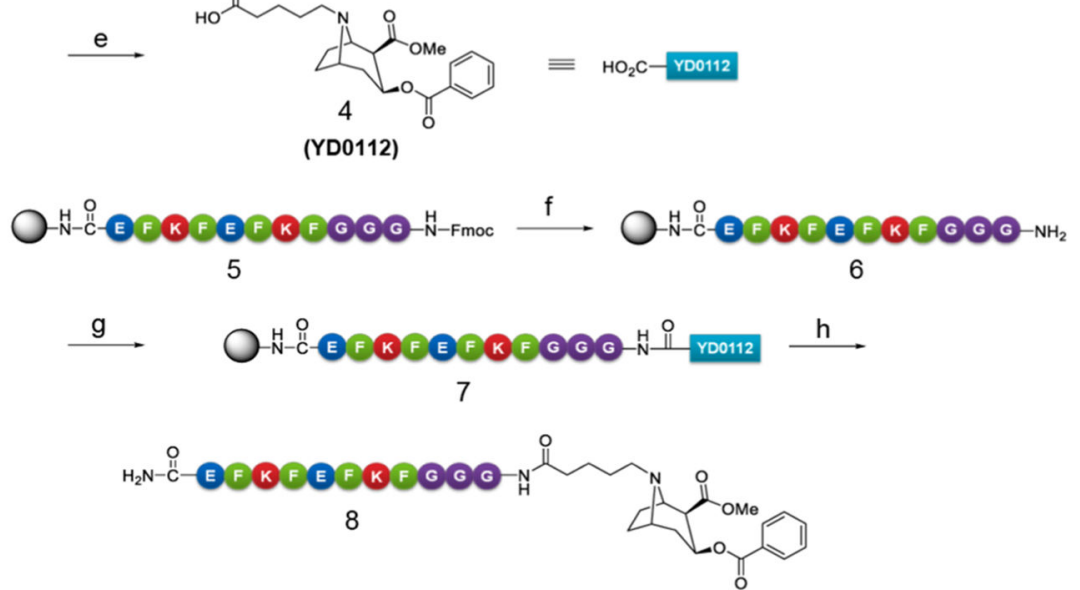

Scheme 1. Synthesis of Novel Cocaine Haptens Modified at the P3 (Cocaine N-site) Site and Conjugation to the Self-Assembling Peptide Domain KFE8 ${ }^{a}$

${ }^{a}$ Reagents and conditions: (a) Saturated $\mathrm{NaHCO}_{3}$ aqueous solution, $\mathrm{CH}_{2} \mathrm{Cl}_{2}, \mathrm{rt}, 1 \mathrm{~h}, 96 \%$;

(b) $\mathrm{CH}_{3} \mathrm{CH}(\mathrm{Cl}) \mathrm{OCOCl}$, 1,2-dichloroethane, reflux, $7 \mathrm{~h}, 91 \%$; (c) $\mathrm{MeOH}$, reflux, $8 \mathrm{~h}, 90 \%$;

(d) $\mathrm{BnOCOCH}_{2} \mathrm{CH}_{2} \mathrm{CH}_{2} \mathrm{CH}_{2} \mathrm{Br}, \mathrm{K}_{2} \mathrm{CO}_{3}$, KI, acetone, $24 \mathrm{~h}, 73 \%$; (e) $\mathrm{H}_{2}, \mathrm{Pd}-\mathrm{C}, \mathrm{MeOH}$, rt, $12 \mathrm{~h}, 75 \%$; (f) $20 \%$ piperidine in DMF, rt; (g) 4, HBTU, DIEA, HOBt, DIC, DMF, rt, $2.5 \mathrm{~h}$;

(h) trifluoroacetic acid/ $\mathrm{H}_{2} \mathrm{O} /$ triisopropylsilane (95\%/2.5\%/2.5\%), rt, $1.5 \mathrm{~h}$. 